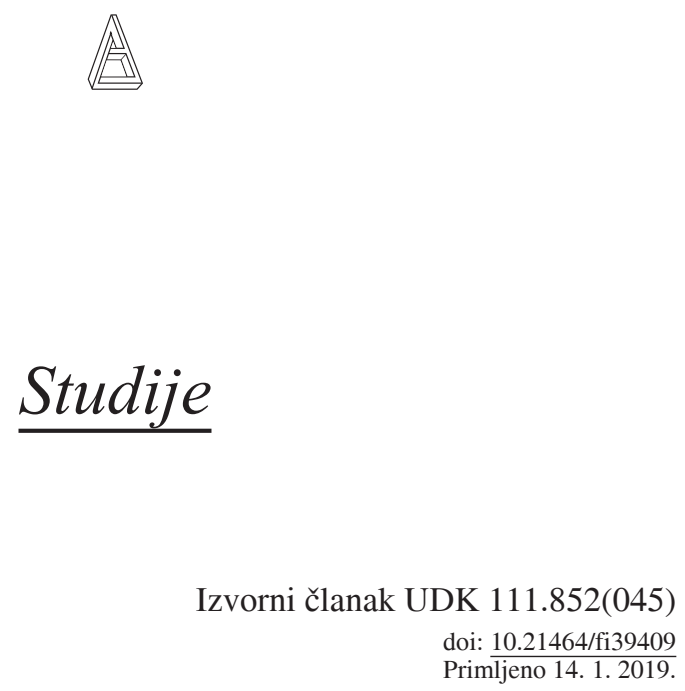

\title{
Dušan Ignjatović
}

Univerzitet Crne Gore, Filozofski fakultet, Ul. Danila Bojovića bb, ME-81400 Nikšić dusan.i@ucg.ac.me

\section{Ontologija lijepoga: metafizički postulati plotinovske kalologije}

\begin{abstract}
Sažetak
Teorija lijepoga igra važnu ulogu u Plotinovoj filozofiji. Ona ima metafizičku, psihološku, etičku i estetičku dimenziju. Neodvojiva je od duhovnog napredovanja i misticizma. Za Plotina, uloga je ljepote u podsjećanju na znanje o idejama. Rezultat toga znanja jest uspon duše istinskoj ljepoti uvježbavanjem u vrlinama i pročišćenjem. Također, njegova estetička teorija, posredstvom lijepoga, traga za krajnjim počelom i teži poistovjećenju s njim. Zato je Plotinova kalologija isto tako važna kao i njegova ontologija. Upravo zbog toga i proširuje značenje onoga lijepog $i$ upućuje na njega u nekoliko svojih eneadskih rasprava (Enn. I. 6., V.8. i VI. 7.).
\end{abstract}

\section{Ključne riječi}

Plotin, teorija lijepoga, ideje, ljepota, duša, sjedinjenje, Jedno, estetika, ontologija, metafizika

\section{1.}

Jedan je od vodećih autoriteta u proučavanju plotinovske misli, glasoviti britanski znanstvenik Arthur Hilary Armstrong (1909. - 1997.), konstatirao u uvodnom dijelu članka koji istražuje pojam lijepoga u Plotina u kontekstu duše i njenoga postupnog otkrivanja božanskog da bi vjerojatno i sam Plotin (204. - 270.) bio veoma iznenađen kada bi otkrio koliko »estetika« - čak i u njezinom modernom značenju - čini prepoznatljiv i respektabilan aspekt njegove filozofije. ${ }^{1}$ Plotin je, ističe ovaj autor, puno promišljao o lijepome u prirodi i umjetnosti, a snažan osjećaj za ljepotu primjetan je gotovo na svakoj razini njegova mišljenja. Zbog toga je taj segment Plotinove misli nerazlučiv

1

Usp. Arthur Hilary Armstrong, »Beauty and the Discovery of Divinity in the Thought of Plotinus«, u: Jaap Mansfeld, Lambertus Marie de Rijk (ur.), Kephalaion. Studies in Greek
Philosophy and its Continuation Offered to Professor C. J. de Vogel, Van Gorcum, Assen 1975., str. 155-163, str. 155. 
od njegova poimanja religije, u istom smislu u kojem je i njegova religija nerazlučiva od njegove filozofije. ${ }^{2}$

Plotinova »estetika $\aleph^{3}$ ili filozofija lijepog ( $\left.\kappa \alpha \lambda \circ \lambda \circ \gamma^{\prime} \alpha\right)$ prožima cjelokupan sadržaj Eneada, a najsistematičnije je izložena u raspravi I. 6. (O lijepom /

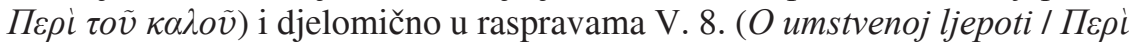

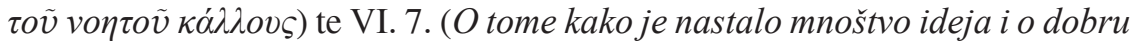

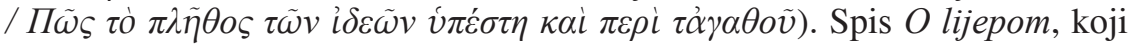
Plotinov učenik i biograf Porfirije (233. - 305.) stavlja na vrh kronološke tablice Plotinovih radova, predstavlja najpoznatiju, najčitaniju i najutjecajniju Plotinovu raspravu, zahvaljujući Marsiliu Ficinu (1433. - 1499.) koji je napravio njen rani prijevod na latinski jezik. ${ }^{4}$ Sama rasprava, s obzirom na to da pripada ranijem Plotinovu stvaralačkom periodu, predstavlja u nekoliko aspekata prikladan uvod u Plotinovu filozofiju, usprkos činjenici što autor u njoj razvija neke od najznačajnijih i najtradicionalnijih platonovskih motiva, osobite one iz Gozbe i Fedra. Sadržaj rasprave može se sažeto opisati kao uspon (’’vó $\beta \alpha \sigma 1 \varsigma)$ duše dobru, ispitivanjem i dohvaćanjem iskustva lijepoga. Drugi traktat (V. 8.) predstavlja drugi dio polemički intonirane tetralogije, poznate kao Die Großschrift. Riječ je zapravo o jednom neobično dugačkom antignostičkom spisu koji je Porfirije kasnije »tematski« razdijelio u četiri različite eneadske rasprave: III. 8. (30), V. 8. (31), V. 5. (32) i II. 9. (33). Taj traktat, koji pripada Plotinovu srednjem stvaralačkom periodu, važan je, po ocjeni Kevina Corrigana, zbog toga što uspostavlja jedan nov način promišljanja o lijepome u prirodi, umjetnosti, duši i umu, a čije začetke nalazimo u izvjesnim misaonim refleksijama Platona, Aristotela i stoika. ${ }^{5}$ Njegovu pro-

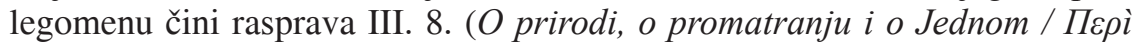

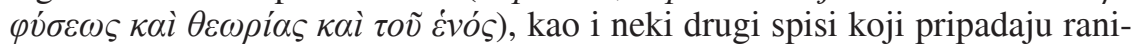
jem stvaralačkom periodu. Također, ističe Corrigan, ta rasprava daje jednu živu sliku o prirodi filozofske dijalektike i na najkonkretniji način ukazuje na mogućnost i limitiranost svake pozitivne estetike u čijoj osnovi leži teorija o umstvenoj ljepoti. ${ }^{6}$ No prije nego što prijeđemo na izlaganje Plotinove ontologije lijepog, podsjetit ćemo najprije na značenje tog izraza u antici.

\section{2.}

Za antički svijet ono lijepo ( $\tau$ ò $\kappa \alpha \lambda o ́ v)$ ima znatno drugačiji i širi smisao u usporedbi s našim modernim shvaćanjem. ${ }^{7}$ Štoviše, moderni osjećaj lijepog

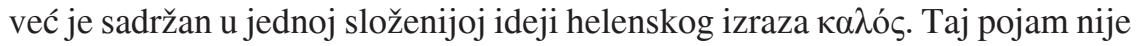
upućivao samo na fizičku ljepotu nego je ukazivao i na jedno opće, pozitivno vrjednovanje raznih drugih simetričnih, fino oblikovanih vanjskih formi, bez obzira radi li se o licu, dijelovima tijela, oružju, građevini ili pak zanatskim tvorevinama. Veza pridjeva $\kappa \alpha \lambda o ́ \varsigma s ~ p o j a v n i m$ stvarima proširuje se i na fizička dobra, u smislu da je taj izraz upućivao na bogatstvo ili blagostanje. ${ }^{8}$ Međutim, ono što ostavlja dojam na svakog suvremenog čitatelja antičke literature jest izrazita etička konotacija tog termina. Nasuprot upućivanju na neku konkretnu ljudsku radnju izraz $\kappa \alpha \lambda o ́ \varsigma$ mogao je ukazivati na žrtvu, čast, dostojanstvo i plemenitost u ponašanju, pravednost, iskrenost, ispravno postupanje i sl. Drugim riječima, taj se pojam odnosio na etičke evaluacije

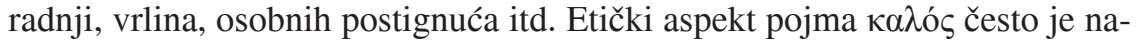
glašavan kod Platona ${ }^{9}$ i Aristotela, ${ }^{10}$ a osobito kod stoika, ${ }^{11}$ za koje on gotovo da postaje sinonim onoga Dobroga ( $\tau$ ò $\alpha \gamma \alpha \theta$ òv). ${ }^{12}$ Ni Plotin, naravno, nije izuzetak, s obzirom da i kod njega taj pridjev ima snažnu etičku i aksiološku konotaciju, što često stvara određene metodološke poteškoće u hermeneutici njegove kalologije. ${ }^{13}$ 
Plotinova analiza fenomena ljepote motivirana je, prije svega, željom i potrebom da pronađe jedno netvarno počelo koje leži u osnovi svega što potpada pod pojam $\kappa \alpha \lambda o ́ s .{ }^{14} \mathrm{Za}$ njega, iskustvo ljepote nije samo stvar subjektivne evaluacije nego je riječ i o jednom »općem karakteru« prisutnom u onim

Usp. ibid.

3

Izraz »estetika« treba uzeti cum grano salis, s obzirom na to da grčki termin $\alpha$ $\sigma \theta \eta \sigma \iota \varsigma$ ne obuhvaća sav smisao i bît Plotinove teorije lijepog ( je riječ za percepciju opažajnih fenomena i upućuje na »ono što se odnosi na osjetila« ili na »ono što pripada percepciji stvari«. Usp. Henry George Liddell i dr., A Greek-English Lexicon: With a Revised Supplement, Clarendon Press, Oxford 1996., str. 42; usp. Dabney Townsend, Historical Dictionary of Aesthetics, Scarecrow Press, Lanham 2006., str. 19). Aï $\theta \eta \sigma ı \varsigma$ je, također, Plotinov naziv za osjetilno opažanje. Međutim, spoznaja lijepoga u plotinovskoj filozofiji zahtijeva više spoznajne moći duše kojima se obuhvaća i nadosjetilna, tj. noetska realnost.

Ficinovi komentari uvršteni su u Creuzerovo izdanje Eneada. Usp. Plotin, Plotini opera omnia. Porphyrii liber de vita Plotini cum Marsilii Ficini comentariis et ejusdem interpretatione castigate, sv. 1, Georg Friedrich Creuzer, E Typographeo Academico, Oxonii 1835 .

Usp. Kevin Corrigan, Reading Plotinus: A Practical Introduction to Neoplatonism, Purdue University Press, West Lafayette 2005. str. 202.

Usp. ibid.

Usp. Władysław Tatarkiewicz, »Classification of Arts in Antiquity«, Journal of the His tory of Ideas 24 (1963) 2, str. 231-240, str. 231, doi: https://doi.org/10.2307/2707847.

Usp. H. G. Liddell i dr., A Greek-English Lexicon, str. 870

Usp. Plat. Phaedr. 279b9; Plat. Gorg. 474d3475a2, 492c; Plat. Sym. 210b6-210c7; Plat. Hipp. Maj. 297e6-298b4.

10

Usp. Arist. Eth. Nic. $1115^{\mathrm{b}} 12-13,1120^{\mathrm{a}} 24$ $25,1122^{\mathrm{b}} 6-7$.

11

Usp. Hans Friedrich August von Arnim (ur.), Stoicorum Veterum Fragmenta [u daljnjem tekstu: SVF], sv. III, Teubner, Leipzig 1903.

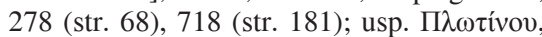

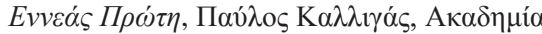

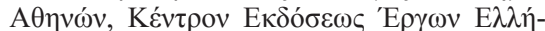

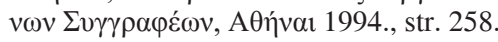

12

Čini se da je kasnije, kod Rimljana, pojam lijepoga bio lišen one pregnantnosti i polivalentnosti koja je bila prisutna u osnovi helenskog

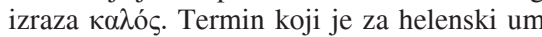
označavao percepciju lijepih oblika, mnoštvenost pojavnosti i koji je na prilično složen način bio povezan s djelatnošću, spoznajom i dobrom, transformiran je u jedan monistički pojam kojem je nedostajala ontološka utemeljenost te koji je u osnovi bio sveden na zanos, šarm, ljupkost i zadovoljstvo. Upravo je taj »umanjeni« osjećaj za lijepo ono što nasljeduje moderni um, kojem ljepota ne predstavlja objektivnu snagu u kozmosu (kao za Helene), nego atribut nečega objektivnog što uzrokuje osjećaj zadovoljstva u subjektu.

13

Ono lijepo ( $\tau$ ò $\kappa \alpha \lambda$ óv) u Plotinovim Eneadama jedna je od onih tema koje se, po pravilu, uvijek javljaju u kontekstu i u povezanosti s drugim temama. Time smo suočeni s delikatnim zadatkom. S jedne strane, prinuđeni smo obratiti posebnu pažnju na metodu kojom se pitanje o lijepom tretira u Eneadama, dok, s druge strane - ako ignoriramo sve ostalo osim referenci koje upućuju na ljepotu - dolazimo u opasnost zanemariti način na koji Plotin piše. Stoga smo prinuđeni kretati se uskom interpretativnom linijom kako ne bismo ispustili iz vida bît Plotinova govora o pojmu lijepoga.

14

Plotinov estetički vokabular poprilično je širok i raznovrstan, iako je katkad lišen preciznosti i jasnoće. Tako su za prvi princip ili Jedno ("Ev) rezervirani izrazi $\kappa \alpha \lambda \lambda$ ovฑ

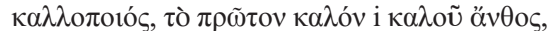
dok se za hipostatski um (Noṽ $\varsigma$ ) koristi izraz

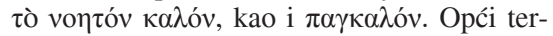

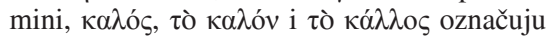
ljepotu u pojavnim stvarima, ali i lijepo kao takvo u višim hipostazama. Što se tiče ostalih

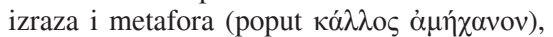
one se, ovisno o kontekstu, odnose ili na Jedno ili na um. Usp. Suzanne Stern-Gillet, »Le Principe Du Beau Chez Plotin: Réflexions sur 'Enneas' VI.7.32 et 33«, Phronesis 45 (2000) 1, str. 38-63, str. 39, doi: https://doi.org/10.1 $163 / 156852800510117$ 
stvarima, pojavama i radnjama koje doživljavamo i opisujemo kao lijepe. ${ }^{15}$ Sadržaj tog iskustva ne uključuje samo opažajnu ljepotu (ljepotu prirode i umjetnosti) nego i apstraktnije, neopažajne, netvarne izraze ljepote, poput ljepotâ običaja, postupaka, znanja, zatim ljepotâ vrlina duše i uma itd. (Enn. I. 6. 1, 1-6). Plotinovo grubo raščlanjivanje različitih manifestacija lijepoga u odjeljku I. 6. 1 na osjetilnu i umstvenu ljepotu, samo je propedeutika glavnom pitanju o nužnim i dovoljnim uvjetima lijepog:

»Šta je to što pokreće poglede promatrača i okreće ih prema sebi, vuče ih i čini da se raduju prizoru? Jer kad bismo to otkrili, možda bismo i služeći se tim kao ljestvama, i ostalo ugledali. 16 $^{16}$

Odgovor cjelokupne predplotinovske filozofske tradicije na to pitanje bio je da se ljepota sastoji u proporciji, odnosno u simetriji dijelova. ${ }^{17}$ Simetrija definira ljepotu kao »suglasje dijelova« i izražava uvjerenost da ljepota ovisi o relaciji i matematičkoj proporciji. Međutim, za Plotina je ta gotovo opće prihvaćena antička definicija lijepoga suviše uska, a što je važnije, u osnovi pogrješna. Kojim argumentima Plotin odbacuje dobru proporciju i boju kao adekvatan uzrok lijepoga? Njegova argumentacija svodi se, u bitnome, na dvije primjedbe: a) definicija ljepote kao simetrije dijelova ne računa na ljepotu nesloženih kvaliteta i pojava; ${ }^{18}$ b) tom definicijom ne objašnjava se ljepota neopažajnih entiteta. ${ }^{19}$ Ako se pitanje ljepote svodi isključivo na pitanje simetričnosti dijelova, jednih prema drugima i u odnosu spram cjeline, onda se po toj analogiji jedino složeni entiteti mogu okarakterizirati kao lijepi. To bi dalje značilo da su i svi dijelovi takvog složenog entiteta podjednako lijepi, zato što ljepota cjeline ujedno podrazumijeva i ljepotu dijelova. Međutim, objašnjava Plotin, među lijepim stvarima postoje i one koje ne posjeduju opažajno razlučive, proporcionalno jukstapozicionirane dijelove. Jednostavni, odnosno nesloženi predmeti ili pojave, npr. boje, sunčeva svjetlost, zlato, zvijezde, bljesak u noći i sl., mogu se također okarakterizirati kao lijepi, iako ne posjeduju proporciju, odnosno opažajno razlučive dijelove. ${ }^{20}$ Kanon ljepote koji počiva na simetriji dijelova još je manje plauzibilan u odnosu na umstvene entitete. Mjera i proporcija, kao kvantitativne kategorije, neprimjenjive su na duhovne kvalitete. Drugim riječima, besmisleno je govoriti primjerice o simetričnosti vrlina, načina života, lijepih običaja ili pak znanosti. Među tim apstraktnim pojavnostima mogu postojati samo logičke veze, odnosno logička dosljednost koja ipak ne može i ne mora biti jamstvo ljepote. I u lošim stvarima ili pojavama može postojati unutarnja harmonija i proporcija, iako je ona u konfliktu s harmonijom cjeline. ${ }^{21}$ Konačno, simetrija ne može biti dovoljan uvjet ljepote zbog toga što neki entitet koji zadržava svoju simetričnost može biti lišen ljepote. Takav je, primjerice, slučaj s beživotnim tijelom koje gubi na ljepoti, iako zadržava svoju proporcionalnost. ${ }^{22}$

Čini se da je, prima facie, Plotinovo odbijanje izjednačavanja ljepote sa simetričnošću u nesuglasnosti s konstatacijom iz kasnijeg traktata u kojem se

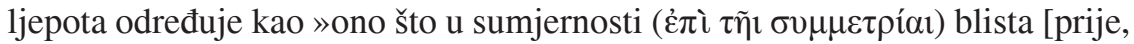
prim. D. I.] nego sama sumjernost $(\sigma u \mu \mu \varepsilon \tau \rho i ́ \alpha v) \ll,{ }^{23}$ kao i s jednim kompliciranim odjeljkom iz petog traktata (Enn. V. 8. 2), koji naizgled implicira kako je složen oblik nužan za ljepotu. ${ }^{24}$ Stvar, međutim, postaje manje zagonetna ako se uzme u obzir da Plotin, u raspravi I. 6. 1, ne polemizira sa stavom da između simetrije i lijepoga postoji međuovisnost, nego s tvrdnjom

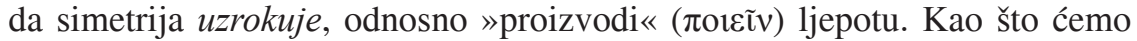
vidjeti, za Plotina simetričnost predstavlja posljedicu i izraz prisustva lijepog, a nikako njegov uzrok. Ljepota se, u jednom umjetničkom djelu, ne postiže mehaničkim nametanjem tipičnih analogija ili »obrazaca«, nego »udahnjivanjem« životnosti koja se reflektira u umnom prauzoru i koji može opaziti 
i spoznati samo dostojan umjetnik. ${ }^{25}$ Ljepota nekih predmeta, doista, može ovisiti o simetriji, ali ti su predmeti samo osjetilne manifestacije jedne idealne forme. Stoga, izvor ljepote nije u simetriji, nego u onom što »otkriva« sebe

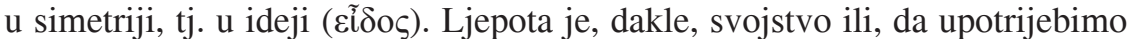

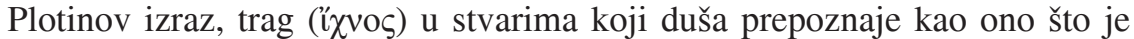
srodno njezinoj bîti.

Lijepe stvari podsjećaju dušu na njezinu duhovnu prirodu, na temelju njiho-

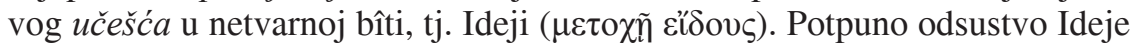
znači krajnju ružnoću; apsolutna ružnoća lišena je božanskog logosa ( $\theta$ cíov $\lambda$ ó ov) i predstavlja potpuni trijumf tvari. Ideja usuglašava, kombinira i objedinjuje fragmentarne i raznorodne dijelove, privodeći ih jednom nedjeljivom jedinstvu, koje mora biti lijepo poput njegovih dijelova. Na taj način

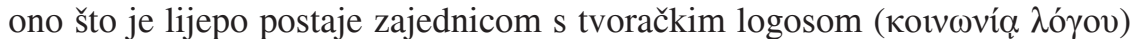
koji potječe iz sfere onoga umstvenoga. ${ }^{26}$ Prisutnost Ideje u pojavnim stvarima razumijeva se na način njezinog učestvovanja u njima, a nikako na način analogijske sličnosti. Sfera pojavnoga ontološki je ovisna o noetskoj i nikada ne postoji sama po sebi i neovisno o višim metafizičkim principima (duše, uma i Jednog). Kao niži aspekt bivstvovanja ona učestvuje u jedinstvenoj cjelovitosti kojoj i sama pripada. ${ }^{27}$ Ta ontološka uvjetovanost, izražena kroz

15

Usp. Donna Ladkin, »Leading beautifully: How mastery, congruence and purpose create the aesthetic of embodied leadership practice«, The Leadership Quarterly 19 (2008) 1, str. 31-41, str. 34, doi: https://doi. org/10.1016/j.leaqua.2007.12.003.

16

Enn. I. 6. 1, 17-20. Za sve navode iz Eneada, osim ako nije drukčije naznačeno, korišteno je izdanje: Plotin, Eneade I-VI, preveo Slobodan Blagojević, Književne novine, Beograd 1984.

17

Usp. Plat. Tim. 87c4-87d8; Plat. Phileb. 64e564e7; Plat. Sym. 196a4-196a8; usp. Arist. Met. 1078 $36-1078^{\mathrm{b}} 1$; Arist. Top. 116 $\mathrm{b} 21-$ 116 22 ; Hrizip, SVF, 3.279; usp. Aleksandar iz Afrodizije, O duši. Dodatak (De anima libri mantissa) Ivo Bruns, 162.12-14, Komentari na Aristotelovu Topiku (In Aristotelis topicorum libros octo commentaria) Maximilian Wallies, 134.18-19, 236.14-16; usp. Ciceron, Tuskulanske rasprave (Tusculanae Disputationes) Max Pohlenz, 4.31.

18

Viktor Vasilevich Bychkov primjećuje da Plotin prvi u povijesti estetike postavlja pitanje o uzroku lijepoga kod jednostavnih pojava.

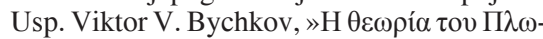

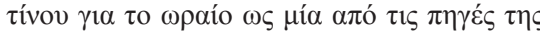

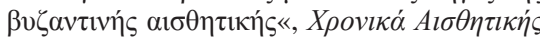
17-18 (1978-1979), str. 107-120, str. 108.

19

Usp. Lloyd Phillip Gerson, Plotinus, Routledge, London, New York 1998., str. 213. O argumentacijskom aspektu Plotinove kritike teorije lijepoga kao simetrije dijelova vidi više u: John P. Anton, »Plotinus' Refutation of Beauty as Symmetry «, The Journal of Aesthetics and Art Criticism 23 (1964) 2, str. 233-237, doi: https://doi.org/10.2307/427785.

20

Usp. Enn. I. 6. 1, 25-40.

21

Usp. ibid., I. 6. 1, 41-54.

22

Usp. ibid., VI. 7. 22, 27-29.

23

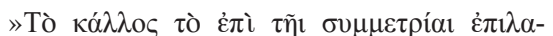

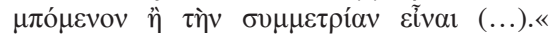
- Ibid., VI. 7. 22, 25-26.

24

Usp. ibid., III. 2. 17, 64-74. Tu Plotin proturječi tvrdnji iz I. 6. 1, 25-40 po kojoj jednostavni, nekompozitni dijelovi nekog složenog entiteta koji doživljavamo lijepim, moraju po toj analogiji biti lijepi per se.

25

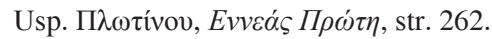

26

Usp. Enn. I. 6. 2; usp. William Ralph Inge, The Philosophy of Plotinus: The Gifford Lectures at St. Andrews 1917-1918, sv. 1, Longmans, Green, and co., London 1918., str. 211-212.

27

Usp. Enn. IV. 7. 8, 2. Treba istaknuti da Plotinova teorija čuva »drugost « učestvujućeg entiteta jer umstveni entitet zadržava svoju neprotežnost, čak i kada je vlastitim energijama prisutan u tijelu. 
suprožetost i duboku povezanost dvije različite razine bivstvovanja, podrazumijeva, između ostalog, da ono što je opažajno učestvuje u lijepome, potom, da je tjelesna ljepota izvedena iz stvarne ljepote, i da, kada opažamo ljepotu u vidljivim stvarima, predosjećamo tračak umstvene ljepote. ${ }^{28}$ Različita svojstva, dispozicije, odnosi itd. u pojavnim fenomenima mogu postojati i neovisno o tvarnom modelu u kojem ih opažamo posredstvom osjetilnog iskustva. To znači da te značajke mogu postojati u tvarnom, ali i u netvarnom obliku. U hipostatskom umu one postoje u čistom, neprotežnom stanju, dok se u njihovom osjetilnom odrazu javljaju u tvarnoj formi; točnije, bivaju eksternalizirane u bezobličnom tvarnom podmetu. Zbog toga smo u mogućnosti doživjeti ljepotu i neprotežnih, apstraktnih entiteta, pojava, ideja i sl. ${ }^{29}$

\section{3.}

Slijedeći, u duhu Platonove Gozbe, različite razine ljepote, Plotin se kreće stazom platonovske anagogije duše ${ }^{30}$ koja vodi od ljepote dostupne osjetilima - shvaćene u njezinom simboličkom i teofanijskom smislu - prema nadosjetilnim oblicima lijepog dostižnima jedino umu. On ne samo što priznaje estetsku kvalitetu neempirijske ljepote nego toj kategoriji lijepog dodjeljuje viši ontološki status u odnosu na opažajnu ljepotu. U Plotinovoj metafizici opažajni fenomeni predstavljaju izraz, odnosno manifestaciju jednog nedjeljivog i bezvremenog umnog arhetipa u prostorno-vremenskoj protežnosti. Slično je i kada govorimo o statusu ljepote spram osjetilnih i nadosjetilnih pojava. Pojavne stvari lijepe su na temelju svog učestvovanja u ideji, dok

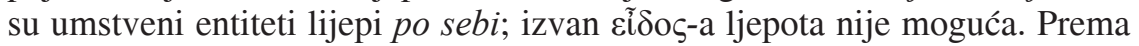
tome, za noetske fenomene ljepota ( $\tau$ ò $\kappa a ́ \lambda \lambda o \varsigma)$ predstavlja intrinzično svojstvo ili, prije, njihovu djelotvornost, dok je za pojavne fenomene ona samo reflektirana slika njihovog transcendentnog uzroka.

Zanimljivo je da Plotin, za razliku od Platona, nigdje ne govori o pojedinač-

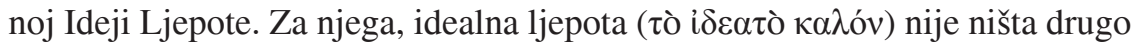
doli jedan zbirni pojam za skup umstvenih entiteta (platonovskih ideja) koji čine sadržaj univerzalnog božanskog Uma. ${ }^{31}$ Stoga, lijepe stvari ne posjeduju ljepotu na temelju učestvovanja u Ideji Ljepote, kao kod Platona, nego na temelju učestvovanja u Ideji uopće, što u Plotinovoj terminologiji predstavlja sinonim za sam hipostatski Um. ${ }^{32}$ To dalje znači da je platonovska Ideja Ljepote, gledano iz plotinovske perspektive, shvaćena kao određeni čin mišljenja Uma koji kao svoj sadržaj posjeduje ljepotu po sebi. Ona je primarna ljepota, kako u smislu uzrokovanja ljepote na svim nižim razinama bivstvene hijerarhije, tako i u smislu predstavljanja izvorne ljepote. ${ }^{33}$ Budući da opažajna ljepota postoji na temelju svojeg učestvovanja u Ideji kao takvoj i da otvarenje znači slabljenje ljepote, onda Ideja per se mora biti ljepša od opažajne ljepote koju stvara. ${ }^{34}$ Ideja ne posjeduje u sebi racionalnu strukturu, primjerice, neke simfonije kao takve ili racionalnu strukturu nekog lijepog lica. Ona je princip svih racionalnih struktura i služi kao temelj svim pojedinačnim slučajevima lijepog u našem iskustvu, iako se ne podudara s bilo kojim od tih slučajeva. Stoga, ona mora biti bezoblična u odnosu na njih, a postaje konkretna forma tek kada je »u nečem drugom «, zapravo u svojim konkretnim slučajevima.

Ono što posjeduje osebujnu formu jest ono učestvujuće; Ideja po sebi daje nešto što konkretna forma kao takva ne posjeduje. Ono što ona posjeduje, ili preciznije, ono što ona jest, izraženo je kapacitetom za generiranje logosnog obrasca na temelju kojega je neka glazbena simfonija ugodna za slušanje, odnosno neko lice ugodno za promatranje. ${ }^{35}$ Slično je i s bilo kojim drugim 
umjetničkim djelom koje ne može biti funkcija tvari, nego samo funkcija oblika prenesenog od strane umjetnika koji »učestvuje u umjetnosti«. Umjetnik podražava ljepotu svijeta Uma i može joj pristupiti izravno, a ne samo kroz medij prirode. ${ }^{36}$ Umstveni arhetipovi, koje opažamo ili doživljavamo u umjetnosti, govore o nečem mnogo ljepšem nego što je ljepota u konkretnom vremenu ili prostoru. U Plotinovu metafizičkom sistemu Ideja je izjednačena sa samim bitkom ( $\tau$ ò eĩvaı) jer ne postoji tvar po sebi, tvar bez bilo kakvog

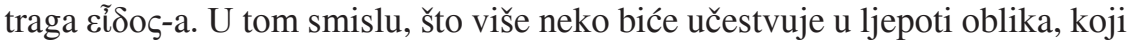
potječe od ideje, to je manje povezan s nebićem tvari, tj. to više jest. To bi u kontekstu plotinovske kalologije značilo da stupanj ljepote odnosno ružnoće ovisi o stupnju prijemčivosti i mogućnosti podležeće tvari da prihvati i zadrži ideju u cijelosti, unatoč njezinoj načelnoj ravnodušnosti pa čak i opiranju da bude oblikovana. ${ }^{37}$ Može postojati samo ono što učestvuje u ljepoti oblika. Što više učestvuje u njoj postaje savršenije i više jest time što je ljepše. Naravno, vrijedi i obrnuto: što je nešto više lijepo, to više jest. ${ }^{38}$

\section{4.}

Percipiranje opažajne ljepote shvaća se kao sposobnost duše da u tijelima prepozna dominaciju ideje, što podrazumijeva podčinjavanje bezoblične i suprotne prirode jednom organskom jedinstvu, suoblikovanom i usuglašenom s idejom kao takvom. ${ }^{39}$ Ideja se, na taj način, javlja i kao osebujnost našeg estetičkog rasuđivanja jer se njome koristimo kao svojevrsnim mjerilom prilikom izvođenja estetičkih evaluacija. O osjetilnim predodžbama lijepoga prosuđujemo imajući kao kriterij jednu drukčiju unutarnju predodžbu, koju

28

Usp. Douglas Hadley, »Plotinus's Defense of the Sensible: The Metaphysics of Image and Dance in Ennead II. 9 (33)«, American Catholic Philosophical Quarterly 71 (1997) 3, str. 453-468, str. 462-463, doi: https://doi. org/10.5840/acpq199771338.

29

Usp. John Fielder, »Plotinus' Copy Theory«, Apeiron 9 (1975) 2, str. 1-11, str.9, doi: https:// doi.org/10.1515/APEIRON.1975.9.2.1.

30

Glagol óvó $\gamma \omega$ i iz njega izvedena imenica

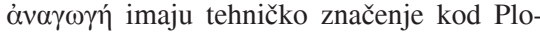
tina i ukazuju na uspon duše Dobru. Inače, izraz ỏv $\alpha \gamma \omega \gamma \eta ́$ prvi put nalazimo u Platonovo Državi, točnije u onom dijelu u kojem Platon izlaže svoju čuvenu alegoriju pećine. Usp. Plat. Rep. 517a5, 512c2, 533d2.

31

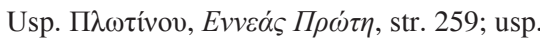
Enn. I. 6. 9, 34-37.

32

Usp. Enn. V. 8. 9, 36-42.

33

Usp. Eyjólfur Kjalar Emilsson, »Cognition and its object«, u: Lloyd P. Gerson (ur.), The Cambridge Companion to Plotinus, Cambridge University Press, Cambridge 1999., str. 217
249, str. 238, doi: https://doi.org/10.1017/ CCOL0521470935.010.

34

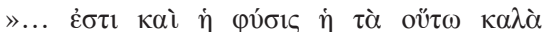

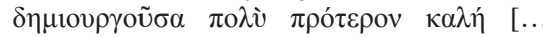
priroda koja proizvodi to što je tako lijepo jest daleko prije (toga) lijepa].«-Enn. V. 8. 2, 31-32.

35

Usp. Cristina D'ancona Costa, »Plotinus and later Platonic philosophers on the causality of the First Principle«, u: Lloyd P. Gerson (ur.), The Cambridge Companion to Plotinus, Cambridge University Press, Cambridge 1999., str. 356-385, str. 372, doi: https://doi. org/10.1017/CCOL0521470935.016.

36

Usp. Enn. V. 8. 1-2.

37

Usp. ibid., I. 6. 2, 16-18.

38

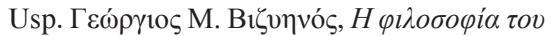

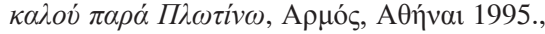
str. 120-124

39

Usp. Enn. I. 6. 3, 5-15. 
posjedujemo zahvaljujući tome što razumska duša intuitivno kontemplira ideju. Drukčije rečeno, duša ima izravan i intuitivan odaziv na ljepotu u pojavnostima. Uzrok te psihološke funkcije počiva na ontološkoj srodnosti opažajno lijepog s višom bîti duše. U ljepoti opažajnih pojava duša prepoznaje »nešto njoj srodno ili trag srodnog (...), vraća se u sebe i prisjeća se i sebe i onog što

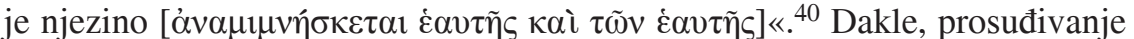
o lijepom nije samo stvar osjetilne percepcije kao takve nego i ostalog dijela duše koji »također sudi usklađujući [lijepo tijelo] s oblikom koji je u njoj i služeći se njime za suđenje kao kanonom ispravnog «. ${ }^{41}$ To znači da su ideje »ispravnosti « $\mathrm{i}$ »ljepote« imanentne višem dijelu duše, odnosno da prethode opažanju ispravnih i lijepih stvari koje nam služe za formiranje opažajnih sudova. ${ }^{42}$ Kroz ljepotu, taj sud podrazumijeva opažanje i utvrđivanje u kojoj je mjeri svaka vanjska manifestacija lijepog lijepa kao takva, u svom disperzivnom stanju.

Istražujući prirodu umstvenog arhetipa onoga lijepog, Plotin poseban naglasak stavlja na anagogijsku funkciju ljepote, prateći put od njezinih osjetilnih manifestacija u prirodi i umjetničkim djelima, prema njezinim umstvenim oblicima; ali i dalje od toga, prema njezinom višem počelu - Dobru. Naše ispitivanje

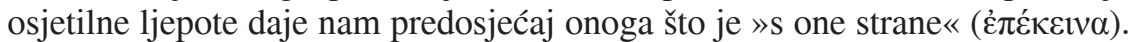
Lijepo, smatra Plotin, treba nas podsjetiti na znanje o Idejama. Svijest o nadosjetilnoj ljepoti znači prelazak duše na višu ontološku razinu, postupno približavanje arhetipskoj ljepoti i potpuno okretanje čistome bivstvovanju umstvenog svijeta. Ovaj anagogijski uspon duše Idejama, tj. istinskoj ljepoti, moguć je jedino uvježbavanjem u vrlini, što u Plotinovoj etičkoj teoriji znači očišćenje

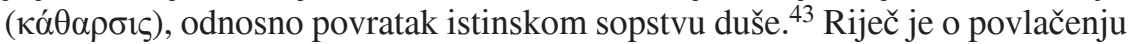
duše u sebe kao posljedici očišćenja od svega što je vanjsko u odnosu spram nje. U tom kontekstu treba razumjeti i sljedeći Plotinov savjet:

»Obrati se sebi i gledaj! Ako još ne bi vidio da si lijep, tada, kao što neki stvaralac slike koja treba biti lijepa, nešto odbacuje a nešto drugo glača, nešto ravna a drugo čisti, sve dok se ne pokaže lijepo lice na slici, odbaci i ti sve što je suvišno i ispravi sve što je iskrivljeno i učini čisteći se da mračno bude svjetlo i nemoj zastati u tesanju svog lika, dok ti ne zasja bogolika slava vrline i dok ne vidiš umjerenost kako sjedi u svetom tronu. $\ll^{44}$

Naša je dužnost, prema Plotinu, napredovati u savršenstvu po uzoru na kipara koji to čini u svojoj umjetnosti. Naime, kada nije zadovoljan svojim radom umjetnik odstranjuje ono suvišno sve dok ne dobije savršenu strukturu. Kada se jednom naša priroda ispuni savršenim jedinstvom ne ostaje ništa osim kontemplacije jer:

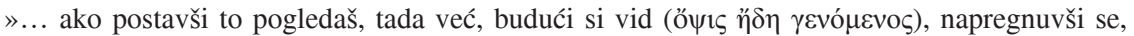
gledaj jer si se odvažio i dovde si se već popeo i više ti ne treba pokazivač. Jedino ovo oko gleda

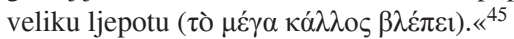

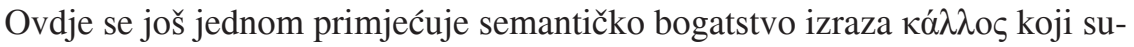
gerira kontinuitet između opažajne ljepote, s jedne strane, i moralnog i umnog savršenstva, s druge. Kao što osoba od rođenja lišena sposobnosti vizualne percepcije ne može biti kompetentna za utvrđivanje kriterija vezanih uz opažajnu ljepotu, tako ni osoba koja ne posjeduje predodžbu o unutarnjoj duhovnoj ljepoti nema kompetenciju raspravljati o njoj. ${ }^{46}$ Plotin zapravo želi istaknuti kako kontemplacija umne ljepote nije dostižna bez odgovarajuće katarzične propedeutike koja duši daje snagu i okrepljuje njezinu volju na putu prema »očinskoj zemlji«. Ružna, odnosno nepročišćena duša, u Plotinovu je

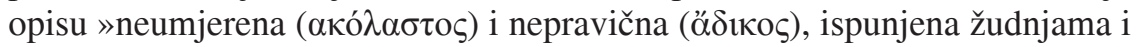
nemirom, i u stalnom strahu od kukavičluka«. Opterećena užitcima i nečistim 
naslagama tjelesnog (tvarnog), duša prihvaća ružnoću kao nešto ugodno, naslađuje se njome i zaboravlja na svoje božansko podrijetlo. ${ }^{47}$ Duša je ružna zbog priklanjanja tijelu i tvari, a jedini je način da ponovno postane lijepa u oslobađanju od svih nečistih primjesa i da se, tako pročišćena, vrati svom istinskom sopstvu:

»Duša, pročistivši se, postaje oblik ( $(\tilde{i} \delta o \varsigma)$, pojam ( $\lambda$ ó $\gamma \circ \varsigma)$, sasvim netjelesna i umstvena i cijela pripada Božanskom gdje je izvor lijepoga i sve ono što je duši srodno. «8

Estetičko napredovanje duše istodobno je i uspinjanje na ontološkoj ljestvici. Duša postaje svoja kada Um i sve ono što iz njega proistječe čini njezinu ljepotu. Stoga se stvarna ljepota, ali i dobrota duše sastoji u postizanju što veće sličnosti s božanskim principom. ${ }^{49}$ Točnije, ljepota duše ovisi o savršenstvu njezinog usklađivanja s hipostatskim Umom i onim Jednim. Spoznaja nutarnje i vječne ljepote zahtijeva čistoću duše i percepciju koja se uzdiže do razine mističkog uvida. Um mora biti u stanju istovremeno prodrijeti i prihvatiti izljev ( $\alpha \pi$ etičko u plotinovskoj filozofiji postaje conditio sine qua non estetičkog napredovanja. ${ }^{50}$ Plotin nam zapravo otkriva da nema napredovanja na ljestvici lijepog sve dok i sami ne postanemo lijepi, odnosno dok se ne su-oblikujemo s onim Lijepim po sebi:

»Onaj koji lijepo gleda kao nešto različito još nije u njemu, već je ponajviše u lijepom ( $\dot{\varepsilon} v$ $\kappa \alpha \lambda(\tilde{\omega} \mathrm{t})$ tako što je postao ono samo. $\ll^{51}$

Točno je da se od duše traži odbacivanje svega onoga što je strano Jednom, ali istodobno postoji i jedan pozitivan proces izgrađivanja i koncentriranja na njezine vlastite moći, sve dok ju potencijal same filozofije, kultiviranjem vrlina i dijalektičkim procesom, ne dovede do točke u kojoj se dostiže savršeno jedinstvo. Moralne vrijednosti u Plotinovoj filozofiji podudaraju se s estetičkim i intelektualnim (umnim), a mogu biti razlučene samo u apstrakciji. Moralna praksa i kontemplacija lijepog vode nas Umu isto tako izravno kao i

40

Ibid., I. 6. 2, 8-11.

41

Ibid., I. 6. 3, 3-5.

42

Usp. Eyjólfur Kjalar Emilsson, »Plotinus on Sense Perception«, u: Simo Knuuttila, Pekka Kärkkäinen (ur.), Theories of Perception in Medieval and Early Modern Philosophy, Springer Science \& Business Media B. V., New York 2008., str. 23-33, str. 31, doi https://doi.org/10.1007/978-1-4020-61257_2.

Usp. John M. Dillon, »An ethic for the late antique sage «, u: Lloyd P. Gerson (ur.), The Cambridge Companion to Plotinus, Cambridge University Press, Cambridge 1999. str. 315-335, str. 319-320, doi: https://doi. org/10.1017/CCOL0521470935.014. 44

Enn. I. 6. 9, 7-15; usp. Plat. Phaedr. $254 \mathrm{~b} 7$.

45

Enn. I. 6. 9, 22-25.
46

Usp. ibid., I. 6. 4, 4-12; usp. Dominic J. O'Meara, Plotinus: An Introduction to the Enneads, Oxford University Press, Oxford 1995., str. 92

47

Usp. Enn. I. 6. 5, 25-48.

48

Ibid., I. 6. 6, 13-18.

49

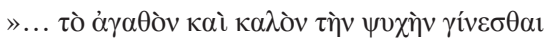

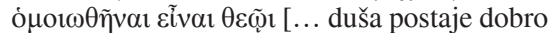
i lijepo kada postane slična Bogu].« - Ibid., I. $6.6,19-20$.

50

Usp. ibid., VI. 7. 22; usp. Stanley Brodwin, »Emerson's Version of Plotinus: The Flight to Beauty «, Journal of the History of Ideas 35 (1974) 3, str. 465-483, str. 478, doi: https:// doi.org/10.2307/2708794.

51

Enn. V. 8. 11, 20-21. 
dijalektičko znanje. ${ }^{52}$ Srž rasprave u traktatima I. 6. i V. 8. upravo predstavlja taj etički aspekt anagogijskog procesa, zato što potraga za ljepotom postaje istodobno i potraga za istinskim bivstvovanjem i njegovim izvorom, Jednim ili Dobrom, koje je i sâmo »najveća i prva ljepota«. Iskustvo tvarne i netvarne ljepote sada je intenzivirano i nadomješteno željom za onim Dobrom. ${ }^{53}$ Istinski eros okreće se od odraza prisutnog u osjetilnoj ljepoti k autentičnom prauzoru ljepote, za razliku od tragičnog mitskog ljubavnika Narcisa koji, opčinjen vlastitim odrazom, postaje prezriv prema istinskom erosu i žrtva vlastitog autoerotizma. ${ }^{54}$ Plotinov gotovo rapsodijski jezik u završnim poglavljima Eneada I. 6. i V. 8. naprosto sugerira da ljepota, uostalom i svi drugi umstveni entiteti, ne pripada onim »stvarima « koje su dostupne potpunoj diskurzivnoj artikulaciji. Uvid u ljepotu po sebi može biti samo ne-diskurzivan i ne-epistemički, tj., iskazano na jedan pozitivniji način, prije je noetički nego dianoetički. Kriterij za umstvenu ljepotu može biti samo um, kao što kriterij za pojavne stvari mora biti naš razum, odnosno diskurzivna funkcija duše. ${ }^{55}$ Međutim, naše iskustvo ljepote ne ograničava se samo na sferu Uma i njego-

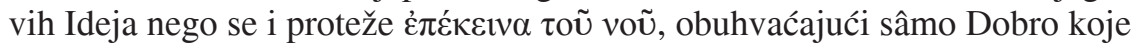

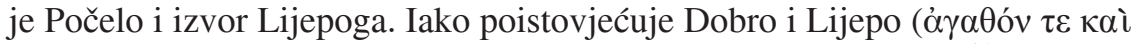

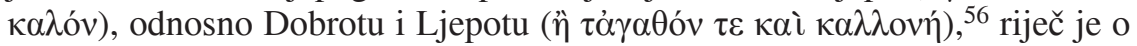
posebnoj vrsti ljepote Jednog koju Plotin opisuje kao »ljepotu iznad ljepote

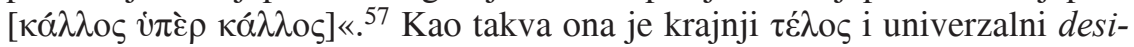
deratum erosa duše. Premda je u početku privučena lijepim stvarima uobličenima Idejom, a potom i samom Idejom (tj. samim sadržajem hipostatskog Uma), urođena kretnja erosa duše usmjerena je Onome što je samo po sebi bezoblično (tj. Jednom ili Apsolutu). Na taj način, paradoksalno, dostići Apsolutnu ljepotu, za Plotina, ne znači opaziti je (intuitivno), nego njoj postati su-oblikovan, odnosno ne biti nešto vanjsko spram nje. ${ }^{58}$

»Prizoru se treba prići nakon što su učinjeni srodnim i sličnim promatrač i promatrano. Jer oko nikad ne bi vidjelo Sunce da nije postalo suncoliko, niti bi duša vidjela lijepo da nije postala

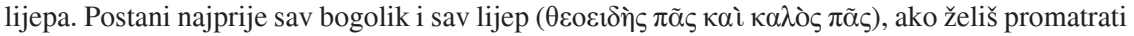
Boga i lijepo. $« 59$

U trenutku sjedinjenja ukida se razlika između subjekta i objekta, duše i njezinog izvora. Tijekom mističke ekstaze pročišćena duša i prvobitni uzrok postaju

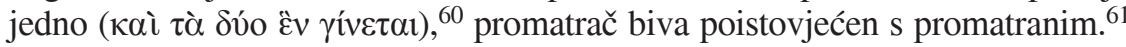
Svojim prelaskom od Uma k onom Jednom duša se suočava s novom ontološkom stvarnošću; zadobiva novi identitet koji podrazumijeva zaokruženje i ispunjenje njezine individualnosti, baš kao što prijelaz od Duše k Umu označuje jedan drugačiji identitet, identitet u kojem Um postaje aktivan i vladajući element. Plotin naglašava da se u stanju mističke kontemplacije čovjek potpuno preobra-

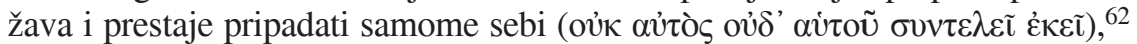
biva pomiješan s najvišim Počelom, uronjen u Njega i jedno s Njim. U trenutku dostizanja mističkog jedinstva prestaje djelovati ne samo racionalnost i svaka umstvenost nego i samo naše sopstvo. ${ }^{63}$ To je stanje u kojem duša živi životom bogova, životom blaženih i božanskih ljudi, potpuno slobodna od stvari ovoga svijeta. Riječ je o životu koji ne nalazi zadovoljstva u ovozemaljskim stvarima, životu bez gibanja, trpnji i bilo kakve žudnje, o životu koji je, kako tvrdi Plotin u posljednjoj rečenici Eneada, »bijeg samoga samome [prev. D. I.]« ${ }^{64}$

\section{5.}

U Plotinovoj se filozofiji lijepog estetičko, etičko i gnoseološko preklapa. Estetičko iskustvo postaje kako iskustvo samospoznaje, tako i iskustvo po- 
vratka našem istinskom, autentičnom sopstvu. Traganje za ljepotom vodi dušu »S onu stranu«ideje, oblika i proporcije, bezobličnom izvoru svake konkretne forme - Jednom ili Dobru. ${ }^{65}$ Težeći Dobru, trebamo se pobrinuti da i sami,

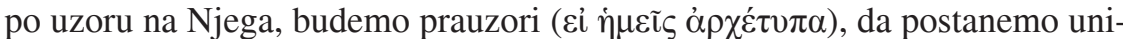
verzalni ( $\tau$ ò $\pi \tilde{\alpha} v)$, poistovjećujući se sa samom božanskom bîti, kako bi i naše

52

Usp. Émile Bréhier, The Philosophy of Plotinus, The University of Chicago Press, Chicago 1958., str. 88 .

53

Usp. Enn. I. 6. 7; usp. D. O’Meara, Plotinus, str. 93.

54

Usp. ibid., I. 6. 8, 8-16, V. 8. 2, 34-35.

55

Usp. ibid., I. 6. 3, 1-5, V. 3. 4, V. 3. 3, 8.

56

Usp. ibid., I. 6. 6, 23-24. Odnos dobrote i ljepote u Plotinovoj filozofiji tema je koja i danas izaziva polemike. Neki smatraju da Plotin izjednačuje Jedno, Dobro i Lijepo (usp. W. R. Inge, The Philosophy of Plotinus, str 124; usp. S. Stern-Gillet, »Le Principe Du Beau Chez Plotin«, str. 38-63; usp. John H. Gay, »Four Medieval Views of Creation«, The Harvard Theological Review 56 (1963) 4, str. 243-273, str. 243-273; usp. Aphrodite Alexandrakis, »Plotinus' Aesthetic Approach to the One «, Philosophia 27-28 (1997-1998), str. 224-235). Drugi inzistiraju na postavci da je ljepota derivativ Jednoga, koje se, iako poistovjećeno s Dobrom, jasno razlikuje od

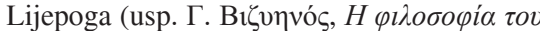

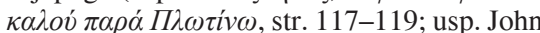
M. Rist, Plotinus: Road to Reality, Cambridge University Press, Cambridge 1967., str. 5365; usp. Werner Beierwaltes, »The Love of Beauty and the Love of God«, u: Arthur Hilary Armstrong (ur.), Classic Mediterranean Spirituality: Egyptian, Greek Roman, Crossroad, New York 1986., str. 300; usp. John R. Bussanich, The One and its Relation to Intellect in Plotinus: A Commentary on Selected Texts, Brill, Leiden 1988., str. 143, 151-152).

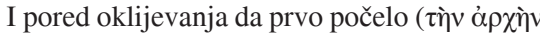

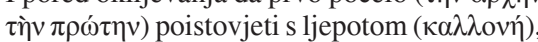
u Eneadama postoje brojne reference koje sugeriraju da Plotin ostavlja otvorenom mogućnost nekog vida identifikacije među njima (usp. Enn. I. 6. 6, 23-24, I. 6. 6, 25-27, I. 6. 7, VI. 2. 18, VI. 7. 32, IV. 8. 1. 3, VI. 9. 4, 18, VI. 9. 9, 47-58, VI. 7. 40, 2). No bez obzira na oblik identifikacije, izraz $\kappa \alpha \lambda \lambda$ ovn ne služi za opis prirode Dobra, nego da bi ukazao na Dobro kao uzročnika lijepog. U

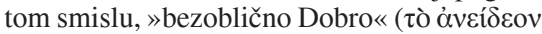
A $\gamma \alpha \theta$ ó) nadilazi pojam lijepoga (koje je u helenskoj misli uvijek i neraskidivo povezano s oblikom ili uobličenjem), a označava se iz-

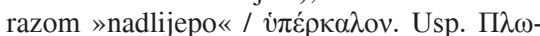

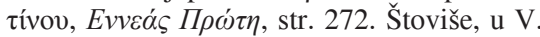

5. 12, 32-36, Plotin nedvosmisleno govori o umstvenoj ljepoti kao mogućoj prepreci napredujućoj duši, odnosno kao prijelazni stadij koji duša mora prevladati ako se želi poistovjetiti a Jednim. »... lijepo sadrži čuđenje, strast i uživanje pomiješano s boli. Ono čak odvlači od Dobra one koji Ga ne poznaju.« - Usp. J. Bussanich, The One and its relation to intellect in Plotinus, str. 143. Judith Omtzigt skreće pažnju na kontekst onih iskaza u kojima Plotin, navodno, poistovjećuje Jedno i ljepotu. Naime, Dobru se zbog njegove apsolutne i na ljubav potičuće prirode pridaje ljepota, ali samo kao subjektivno svojstvo, zasnovano na njegovoj sposobnosti da ispuni i najdublje težnje moralno napredujuće duše. Međutim, kada se o Dobru govori objektivno i strogo metafizički Plotin nema dilemu da je ono, kao beskrajno i bespočetno načelo $1 j$ epote, »nešto starije i ranije od ljepote«. To pripisivanje ljepote Jednom/Dobru može se usporediti s pripisivanjem simetrije umu. Za um se kaže da je simetričan, iako je jasno da on nadilazi svojstvo simetričnosti jer umstveni svijet ne poznaje prostorno-vremenske kategorije. Usp. Judith Omtzigt, Die Beziehung zwischen dem Schönen und dem Guten in der Philosophie Plotins, V\&R Unipress, Göttingen 2012., str. 87-89.

57

Enn. VI. 7. 32, 29

58

Ibid., V. 8. 11; usp. Monroe C. Beardsley, Aesthetics from Classical Greece to the Present: A Short History, The University of Alabama Press, Tuscaloosa, London 1975., str. 86. Pla-

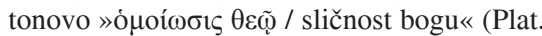
Theaet. 176b), u plotinovskoj verziji označava uzdizanje duše »s onu stranu « ograničenih ideja prema bezgraničnom Jednom, čija se beskonačnost posvuda naglašava u Eneadama. Usp. J. Rist, Plotinus, str. 217. Koristeći se poznatom gnoseološkom izrekom »őhorov

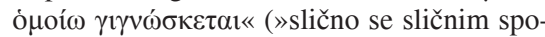
znaje)«, Plotin želi pokazati da je jedinstvo s Jednim dostižno na temelju prirodnog srodstva najvišeg dijela duše s izvorom svega postojećeg. Upravo iz tog razloga svjesno izostavlja

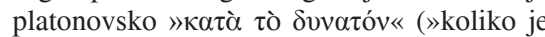
moguće «). Prema tome, krajnja svrha duhovnog napredovanja nije samo kontemplacija Dobra nego i sjedinjenje s njim - sjedinjenje u kojem i sama duša postaje Jedno.

59

Enn. I. 6. 9, 29-34. 


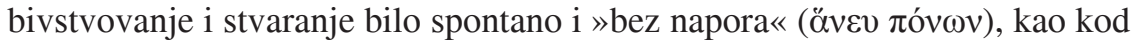
Demijurga. Kada čovjek prestane biti ne-autentično bivstvujuće (drugo-biće), odnosno kada, po mišljenju Plotina, više ne bude osjetilan i individualan, uzdići će se i postati pričesnik sveopćeg stvaranja. ${ }^{66}$ Gledano iz više, makrokozmičke perspektive, subordinacija Lijepog spram Dobra jasnije se zamjećuje. Dobro i urođena, nesvjesna želja za njim prethodi ljepoti pa čak i onoj par excellence Ljepoti svijeta Uma i njezinoj svjesnoj uznemirujućoj želji koja

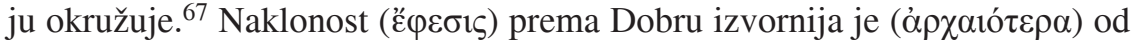
naklonosti prema Ljepoti. Težnja onom lijepom nastaje kada se u danome trenutku i na određenome mjestu nađemo pred nekom lijepom pojavom ili nekim lijepim predmetom. Težnja Dobru, s druge strane, oduvijek je prisutna u nama svjesno ili pak nesvjesno, s obzirom na to da je i samo Dobro prirođeno

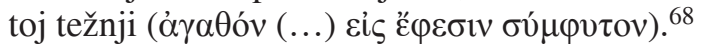

Uspostavljanjem aksiološke razlike između Lijepog i Dobra Plotin zapravo ocrtava granice i domete vlastite filozofije lijepoga koja se sada podvrgava jednoj općenitijoj etičkoj perspektivi cjelokupnog anagogijskog procesa. $\mathrm{Na}$ taj se način njegova $\kappa \alpha \lambda o \lambda o \gamma i ́ \alpha$ potpuno uklapa u jedinstvenu etičko-estetičku teoriju po kojoj ljepota pojavnosti ovisi isključivo o stupnju njene participacije u prirodi najskrovitije stvarnosti. Sva bića teže apsolutnom nerazlučivom jedinstvu s božanskim prauzorom, nastojeći ostvariti vlastiti potencijal za savršenstvom i stremeći stanju »blažene punine « $\mathrm{i} » v j e c ̌ n o g ~ p r o s v j e t l j e-$ nja u kojem se iskustvo lijepog i ljubavi doživljava u svoj njihovoj čistoći. 


\title{
Dušan Ignjatović \\ Ontology of Beauty: The Metaphysical Basis of Plotinian Kalology
}

\begin{abstract}
The theory of beauty plays an important role in Plotinus's philosophy. It has metaphysical, psychological, ethical, as well as aesthetical dimension. It is also inseparable from the spiritual ascent and mysticism. For Plotinus, the role of beauty is to recall to us a knowledge of forms. Thus, soul ascends to the true beauty through the practice of virtues and its purification. His aesthetic theory searches for a way to the ultimate principle in terms of beauty, and by doing that it seeks to identify a soul with it. This is why Plotinus' theory of beauty is as important as his ontology, and why he significantly extends the meaning of the beautiful and refers to it in several books of his Enneads (i.e. I. 6., V. 8. and VI. 7.).
\end{abstract}

\section{Key words}

Plotinus, theory of beauty, ideas, beauty, soul, union, One, esthetics, ontology, metaphysics

60

Usp. ibid., VI. 7. 35, 36.

61

Usp. ibid., VI. 9. 11, 6-7.

62

Usp. ibid., VI. 9. 10, 15-16.

63

Usp. ibid., VI. 9. 11, 11-12.

64

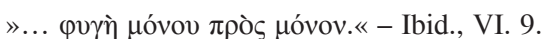
11, 50-51. Treba naglasiti da jedinstvo s Jednim ne znači ukidanje ili poništenje individualnog postojanja duše, nego njeno zaokruženje $\mathrm{i}$ ispunjenje. Riječ je, kako primjećuje Pierre Hadot, o jednom misticizmu u kojem dolazimo do stanja da možemo reći kako umiremo za vlastitu individualnost, ali čija je cijena zadobivanje pristupa unutarnjoj spoznaji i univerzalnosti misli svega. Usp. Pjer Ado [Pierre Hadot], Duhovne vežbe $i$ antička filozofija, prevela Suzana Bojović, Fedon, Beograd 2015., str. 68-69. Na taj način, paradoksalno, ono što je najintimnije u nama postaje najneosobnije. Unutarnjost, za Plotina, kako primjećuje Jean-Marc Narbonne, ne znači povlačenje u sebe nego otvorenost. Takva otvorenost ne leži u temelju personalnosti, nego u cjelini koja nas vodi iznad bilo kakve restriktivne predodžbe o individualnosti. Duša je istinsko sebstvo tek kada je odvojena od svega, uključujući i svjesnost koja je fragmentira i odvlači od njezine stvarne djelatnosti. Usp. Jean-Marc Narbonne, »Action, Contemplation and Interiority in the Thinking of Beauty in Plotinus «, u: Aphrodite Alexandrakis (ur.), Neoplatonism and Western Aesthetics, State University of New York Press, Albany 2002., str. 13-14.

65

Usp. Enn. VI. 7. 33.

66

Usp. ibid., V. 8. 7, 28-40.

67

Usp. ibid., V. 5. 12; usp. Arthur Hilary Armstrong, Plotinus, George Allen and Unwin Limited, London 1953., str. 66.

68

Usp. ibid., V. 5. 12, 11-19. 